\title{
Sağlık Politikalarını Covid-19 Pandemisi Üzerinden Anlamak İçin Kilit Bir Kavram: Biyo-Politika
}

Yücel UYANIK*

Tuğba GÜCENMEZ**

Geliş Tarihi (Received): 02.09.2020 - Kabul Tarihi (Accepted): 14.10.2020

\section{$\ddot{O} \mathbf{z}$}

Küresel salgın hastalıklar, insanlık tarihinde doğal afetler ve savaşlar kadar yıkıcı etkiler yaratımıştır. Ciddi ekonomik ve siyasal krizler yaratan salgın hastalıklarla mücadelede sağlık politikalarının uygulanış biçimi öne çıkmaktadır. İktidar sahiplerinin ideolojisine göre insan ve toplum sağlığı, dolayısıyla toplumsal refah da yönetilmektedir. Bu noktada, Foucault'un biyo-politika kavramı akıllara gelmektedir. İnsan bedeninin siyasi strateji aracı edilerek ekonomik çıkarlara ulaşma amacı, neo-liberal dönemde ve özellikle sağlık politikalarının yürütülmesinde hala güdülmektedir.

Bugün küresel faturası çok ağır olacak olan COVID-19 pandemisi tekrar siyasi, ekonomik ve sosyolojik sistemleri biyo-politika üzerinden sorgulamamızı gerektirmiştir. Yeni bir virüsten kaynaklanan bu bulaşıcı hastalık, insanların günlük hayat rutinlerini ve toplumların sosyo-ekonomik ilişkilerini de sekteye uğratmıştır. Bu hastalıktan kurtulmak için gözlerin sağlık sektörüne çevrildiği bu dönemde, çalışmamız sağlık politikalarını biyo-politika üzerinden tartışmayı hedeflemektedir.

Anahtar Kelimeler: Sağlık Politikaları, Küreselleşme, Foucault, Biyo-Politika, COVID-19, Pandemi.

\section{A Key Concept For Conceiving Health Policies Over Covid-19 Pandemic: Bio-Politics}

\begin{abstract}
Global epidemics have had devastating impacts throughout the human history as natural disasters and wars. The way of implementing health policies has come to the fore in the fight against epidemics causing serious economic and political crisis. The health of human and society and, therefore the social welfare are also governed according to the ideology of the ones in power. At this point, Foucault's concept of bio-politics comes to mind. The aim of achieving economic interest by transforming human body into a political strategy still continues in this neo-liberal period, especially in conducting health policies.

Today, the COVID-19 pandemic, which will possibly have a very heavy global cost in the future requires us to question the political, economic and sociologic systems over bio-politics again. This pandemic caused by a new virus has also interrupted people's daily routines and socio-economic relations of societies. In this period when the health sector is at the forefront for recovering from this pandemic, this paper aims at discussing health policies over bio-politics.
\end{abstract}

Keywords: Health Policies, Globalization, Foucault, Bio-politics, COVID-19, Pandemic.

\footnotetext{
* Prof. Dr., Ankara Hacı Bayram Veli Üniversitesi, İktisadi ve İdari Bilimler Fakültesi, Çalışma Ekonomisi ve Endüstri İlişkileri Bölümü, y.uyanik@hbv.edu.tr

*** Arş. Gör., Adıyaman Üniversitesi, Fen Edebiyat Fakültesi, Sosyoloji Bölümü, tgucenmez@adiyaman.edu.tr
} 


\section{Giriş}

Göçebe nüfusların yerleştirilmesi, isyanları önlemek amacıyla yerlerinin değiştirilmesi, nüfus sayımları yoluyla sayılaştırılması, iktidar araçlarını kullanarak ve şiddet ${ }^{1}$ uygulayarak sayılarının kontrol edilmesi, yeniden üretimin yasaklanması veya teşvik edilmesi suretiyle kontrol edilmesi, başka bir ifadeyle devletin yeni bir toplum yaratması olarak tanımlanabilecek biyo-politika, makalemizin merkezinde yer alacak kavramdır. Foucault, bu kavramı modern devletin doğuşu olarak kullanırken, disiplin mantığını topluma yayan hapishane, tımarhane ve hatta üniversite gibi kurumların etkilerini araştırma yöntemini izlemektedir. İktidar, nüfusu oluşturan bedenleri kontrol altına alarak toplumsallaştırmaktadır. $\mathrm{Bu}$ noktada hayat artık iktidarın yalnızca nesnesidir. İktidarın işlevi sadece hayatı kuşatmak ve yönetmek değil, ayrıca bireylerin yeniden üretimini de üstlenmektir. Küreselleşmenin sağlık politikalarına olan etkisi de en çok bu alanda kendisini hissettirmektedir. Sistemin sağlık politikalarını anlamak için bu biyo-politika kavramının iyi anlaşılması gerekir. Çünkü küreselleşen bir dünyada bedenlerin üretime dahil edilmesi mümkün olduğu için, sistemin varlığını sürdürecek biyo-politikalara ihtiyaç vardır:

İktidar ilişkileri beden üzerinde doğrudan bir müdahalede bulunmaktadır. Bedenin siyasal olarak kuşatılması onun ekonomik kullanımına bağlıdır. Bedenin iktidar ve egemenlik ilişkileri tarafından kuşatılmasının nedeni büyük ölçüde üretim gücü olmasından kaynaklanmaktadır, fakat bedenin işgücü olarak oluşması ancak onun bir tabiiyet ilişkisi içine alınması halinde mümkündür; beden ancak hem üretken beden, hem de tabii kılınmış beden olduğunda yararlı bir güç haline gelebilmektedir (Foucault, 1992, s.33).

Nüfus sağlıklı olduğunda devlet gelişimini sürdürebilmekte ve tüm insanlık üzerinde eksiksiz bir kontrol sağlanabilmektedir. Bireyler, nefes alıp yaşayan, tat alan, koklayan, okuyan, konuşan -ve sistem için en önemlisi- çalışan bir mekanizmadır. Bu bireylerin bir arada oluşu halkı meydana getirir. Küresel sistemin sağlık politikalarına göre bedenlerin denetimli biçimde üretim aygıtına dahil edilmesi gerekirken aynı zamanda nüfus olaylarının da ekonomik süreçlerle paralel bir çizgide yol alması gerekmektedir. $\mathrm{Bu}$ durumu açıklayabilmek adına küreselleşme ve sağlık teknolojileri kavramlarının iyi anlaşılması gerekmektedir.

\footnotetext{
1 Buradaki şiddet, doğası gereği şiddet içermeyen ama işleyiş biçimi nedeniyle yaptırım oluşturan iktidar yapisidir.
} 


\section{Küreselleşme}

Küreselleşme kavramının kökeni ilkel toplumlara kadar götürülmekle birlikte kavrama dair literatürdeki ilk çalışma, Aralık $1968^{\prime}$ de International Studies Quarterly dergisinde yayınlanan Communism and Globalization of Politics adlı makalesiyle, (Küreselleşme kavramını ilk kez kullanan) George Modelski' ye aittir (Yalçınkaya, 2010, s.7). Modelski, küreselleşme kavramına politik açıdan yorum getirmiştir. Modelski’ ye göre küreselleşme, uluslar, medeniyetler ve siyasal topluluklar arasındaki genel dayanışmanın genişlemesinin ve derinleşmesinin tarihsel sürecini kapsayan bir kavramdır (Held ve McGrew, 2008, s.71 aktaran Kürkçü, 2013, s.1).

Küreselleşmenin ortaya çıkma nedenleri, özellikleri ve sonuçları düşünüldügünde tek boyutlu bir tanım ya da açıklama getirilmesi mümkün değildir. Özellikle, 1980’ lerden beri neo-liberal iktisat politikaları ile bağlantı kurulmaktadır. Muray Rohtbard ve David Friedman gibi liberal düşünürler, 1970'li y1llardan itibaren 'piyasaların serbestliği ilkesi' ni çalışmalarının merkezine koymuşlar böylece 'bırakınız yapsınlar' şeklindeki liberal ideolojinin geçerliliğini kanıtlamaya çalışmışlardır (Kürkçü, 2013, ss.1-2).

Küreselleşme, son zamanlarda kapitalizm ile birlikte daha çok anılmaktadır. Ancak, Üçüncü ve Dördüncü Sanayi Devrimlerinin özellikleri olarak teknolojik ve iletişimsel gelişmeler, küresel anlamda gerçekleşmektedir. Dolayısıyla, veri aktarımında uydu teknolojilerinden faydalanılması, bilginin saklanması, depolanması, işlenmesi ve iletilmesinde dijital ortamlardan yararlanılması ve iletişim araçlarının üretim maliyetlerindeki hızlı düşüş², küreselleşmenin daha fazla alana yayıldığını ve türevlendiğini göstermektedir.

Küreselleşmenin, özellikle neo-liberal sistemde, sosyal politika açısından bakıldığında kalkınmanın lehine mi yoksa aleyhine mi olduğu sorusunun cevabı önemlidir. Eğitim, sağlık, ulaşım gibi kamu hizmetlerine herkes tarafından erişilebilir kılmak, sosyal devlet uygulamalarını adil bir şekilde gerçekleştirebilmek, yerel ve küresel kalkınma için gereklidir.

Sağlık politikalarının düzenlenmesi ve uygulanması, bu konudaki teknolojik gelişmeler de; küreselleşme, kapitalizm ve makalemizin çıkış noktası olan biyo-politikanın yorumlanması bağlamında değerlendirilecektir.

\footnotetext{
${ }^{2}$ Bayar, 2008, s.29.
} 


\section{Biyo-politika}

Her ne kadar giriş bölümünde biyo-politika kavramının Foucault tarafından modernizm ile ilişkilendirildiğini söylediysek de, kavramı bazı kaynaklar yüz yıl öncesi filozofları Schopenhauer ve Nietzsche'ye dayandırmaktadır (Lemke, 2013, s.25). Bu kavramı esas alan düşünürlere göre politika, kendine biyolojik yasalar çerçevesinde şekil vermektedir.

Biyo-politikanın etkili bir silah olarak kullanıldığı dönem Nasyonal Sosyalizm dönemidir. Demokrasi karşıtı bu dönemde, ırkçı bir eğilime sahip organik muhafazakar devlet "halkın bedeni" (volkskörper) kavramına başvurmuştur. Bu kavram, hiyerarşik yapıdaki homojen ırktan oluşan topluluğu tanımlamaktadır. Bu ideoloji, toplumsal ilişkilerin ve politikaya konu olan meselelerin biyolojik gerekçelere dayandığını savunmuştur (Lemke, 2013, s.27). Nazi döneminde halk ile devlet biyolojik açıdan birlikte temellendirilmiştir. Hitler' in yürüttüğü politika gereği nüfusun artması ama halkın genetik açıdan nitelikli biçimde gelişmesi için, biyolojik açıdan değerli olarak görülen özelliklerin desteklenmesi ve 'aşağılık sınıflar' ın zararlı özelliklerinden kaçınılması zorunlu kılınmıştır. Görüldüğü üzere, tarihin bu karanlık döneminde biyo-politikanın anlamı, toplumların yaşamını etkilediği kadarıyla genetik süreçlerin tümünün kaydını tutmaktır.

Aynı yıllarda Amerika Birleşik Devletleri'ndeki politikalar Nazizm'den farklı değildir. Moleküler biyolojinin doğuşunu fonlayan Rockefeller Vakfı, bilimin yeni bilgiyle birlikte toplumsal denetim araçlarını geliştirmesini ve insan davranışını yönlendirip devletine zeval getirmeyecek hayırlı vatandaşlar yetiştirilmesini savunmuştur (Kay, 1993).

Biyo-politika üzerine çalışan akademisyenlerin uzlaşı sağladığı üç yaklaşım bulunmaktadır. Bunlardan ilki, biyo-politikanın araştırma nesnesinin politik davranış olduğu yönündedir. Bu yaklaşıma göre politik davranış, kanıtlanabilir biçimde biyolojik etmenlere bağlıdır. Kültürel etmenlerin etkisi kısıtlı olduğu savunulur. Diğer yaklaşıma göre politikanın, biyolojik zorunluluklarla tutarlı olabilmesi için gözlemlenebilir davranışın tanımlanması ve açıklanması gerekmektedir. Son yaklaşıma göre ise, belli davranış biçimleri, kurumsal süreçleri nesnel olarak betimleyen dışsal bir gözlemciye ihtiyaç duymaktadır (Lemke, 2013, s.34).

Toplum bilimlerine yönelik geliştirilen biyo-politik eleştiriye göre, toplum bilimleri insanların özgür olduğu gibi yanlış bir varsayıma dayalıdır. Bu görüş, eğitim sürecine aşırı bir anlam yüklemektedir. $\mathrm{Bu}$ nedenle insan davranışının biyolojisi ile koşullandığı göz ardı edilmektedir. $\mathrm{Bu}$ indirgemeci yaklaşıma karşı çıkan biyo-politikacılar tek boyutlu model 
yerine bütünleşik bir model önerirler. Bunun için de toplum bilimleri ile biyolojik görüşlerin birleştirilmesi gerekmektedir (Lemke, 2013, s.35).

Buradan hareketle biyo-politika çalışan akademisyenler, toplumdaki hiyerarşinin de bir fenomen değil, evrimin kaçınılmaz bir sonucu olduğunu savunur. Çünkü onlara göre sabit ilişkiler genlerle bir sonraki nesle aktarılarak, asimetrik bölüşüm firsatı bir avantaj olarak ortaya çıkmaktadır. Kıt kaynaklar için mücadele gibi rekabet gerektiren durumlar insanları eşitsiz kılmış ve buradan da her türlü hiyerarşik kurumlar doğmuştur.

Foucault, Hitler faşizmini yaratan şeyin bireyleri ekonomik ilişkilere dahil etme gayesinde olan küresel dengelerin de haricinde her bireyde bulunan iktidar arzusunun neden olduğunu şu şekilde ifade etmektedir:

Arzu, iktidar ve çıkar arasındaki ilişkiler genellikle sanıldığından daha karmaşıktır ve iktidarı uygulayanların onu uygulamaktan çıkarları olanlar olması gerekmez; iktidar uygulamaktan çıkarı olanlar iktidar uygulamaz ve iktidar arzusu ile çıkar arasında hâlâ tekilliğini koruyan bir oyun oynar. Faşizm anında, kitleler bazılarının iktidar uygulamasını isteyebilir, bununla birlikte iktidar uygulayacak bu bazıları kitleler değildir; çünkü iktidar kitleler üzerinde ve onların zararına, ölümlerine, kurban edilmelerine, katledilmelerine varıncaya kadar uygulanacaktır ve kitleler yine de bu iktidarı arzular (Foucault, 2000, s.39).

1960’l1 yıllara gelindiğinde biyo-politika başka anlamlara gelmeye başlamıştır. $\mathrm{Bu}$ yeni dönemde kavram, politikanın biyolojik temellerine odaklanmak yerine, politik eylemin yeni nesnesi olarak hayatı ortaya koymaktadır. Bir diğer ifadeyle kavram, politikada yeni bir alan açarak, insanlığın doğal çevresinin korunması amacını taşıyan eylem olarak tanımlanmaktadır. Çevrenin korunmasının haricinde insanlığın geleceğini ilgilendiren sağlık politikaları ve nüfus kontrolü de biyo-politikanın ilgilendiği meselelerdir (Lemke, 2013, ss.41-42). Özetle, biyo-politika, nüfus yönetimi ve liberal politikalar ile uyumlu rasyonel davranışların siyasete yansıtılması ile ilgilidir. Rasyonel nüfus yönetimi ve siyaset anlayışını sürdürürken sağlık teknolojisini en iyi şekilde kullanmak da önceliklidir.

\section{Sağlık Teknolojisi}

Sağlık teknolojisi, Dünya Sağlık Örgütü tarafından 'bir sağlık sorununu çözmek ve yaşam kalitesini iyileştirmek için geliştirilen cihazlar, ilaçlar, aşılar, prosedürler ve sistemler şeklinde organize bilgi ve becerilerin uygulanması' ${ }^{3}$ olarak tanımlanmaktadır.

Küreselleşme sonucunda etkin sağlık hizmetinin sağlanabilmesi için sınırlı kaynakların verimli şekilde kullanılması gerekmektedir. Hangi teknolojinin daha etkili olduğu, hangisinin daha güvenli olduğu, etik ve yasal olduğu gibi konuların haricinde sağlık hizmetlerine adil ve eşit erişim imkanı sağlanması da günümüzde iktidarların ellerinde tuttuğu önemli silahlardandır. Toplumun her kesiminin sağlık hizmetlerinden alacağı faydayı yüksek

\footnotetext{
${ }^{3}$ https://www.who.int/medical_devices/assessment/en/ (Erişim Tarihi: 01.11.2018).
} 
seviyede tutmak devletlerin göreviyken, küresel liberal çıkarlar nedeniyle devletlerin sağlık hizmetlerinde dahi kar amacı gütmesi kaçınılmazdır.

Modern sağlık teknolojileriyle beraber ilerleyen biyo-teknolojik yeniliklerden ilki sayılabilecek DNA transferinin 1970'li yıllarda mümkün olmasıyla beraber, farklı organizmalardan alınan genlerin ayrıştırılıp yeniden şekillendirilmesi imkanı oluşmuştur. Yine bu yıllarda fetüsün görüntülenmesi ve tüp bebek gibi üreme teknolojilerinin geliştirilmesi, bilimsel süreçlerin denetim ve düzenlenmesine yönelik kaygılarda artışa neden olmuştur. Bu gelişmelerin sonucunda kültür ile doğa arasındaki sınırın kırılganlığı ortaya çıkmış, bu nedenle de politik ve yasal sınırlılıklar geliştirilmek zorunda kalınmıştır (Lemke, 2013, ss.44-45). Hangi sürecin, hangi yöntemle, hangi koşullar altında uygun olduğunun düzenlenmesi ve biyo-teknolojik araştırmaların kamu tarafından ekonomik olarak desteklenmesi ya da yasaklanması da devletin insanlığa karşı kullanacağı iktidar mekanizmalarından birini oluşturmuştur.

Sağlık teknolojileri ile birlikte hayatın yararlarının biyolojik açıdan artışı ve tıbbı müdahalelerle hayat süresinin uzaması sağlanmaktadır. Şüphesiz ki bu süreç doğumla başlamaktadır. Hatta doğum öncesinde yapılan tetkiklerle bebeğe konulan tanılar ebeveynleri karar almak zorunda kalacakları bir sürece sürüklemektedir. Örneğin bebeğin zihinsel ya da fiziksel bir engelle doğup doğmaması, ebeveynin kürtaj seçeneğini kullanıp kullanmama seçeneğini yaratmıştır. Ayrıca, kürtaj gibi kadının bedenine dair kararlar zaman zaman küresel kapitalist politikaların malzemesi haline gelmektedir. Bunun da dışında embriyonik kök hücrenin hukuki bir özne olup olmaması, norm-biyolojinin özgür iradeye müdahale edip etmediği gibi sorular da biyo-politikanın cevaplanamayan sorularıdır. Burada esas sorun bu sorulara verilecek yanıtları alacak karar mekanizmasında kimlerin etkili olacağıdır (Lemke, 2013, ss.48-50).

Yalnızca doğurganlık sorununda değil, insan yaşamı ile doğrudan ilişkili olan hastalıkların yönetiminde de bir zihniyet değişimi söz konusudur (Arpacı, 2016, s.92). İktidar bu noktada devreye girmektedir.

Foucault' nun eserlerinde kullandığı teknoloji kavramına yüklediği anlamlar, filozofun kavramı liberalizm ile ilişkilendirdiğini göstermektedir. Biyo-teknolojik mekanizmalar, tehlike altındaki nüfusun özgürlüğünü düzenleyip, onları koruyup kollama iddiasındadır. Fakat bu müdahaleler bir tür disiplin içermektedir. Disiplin ile, normal-anormal arasındaki ayrım yeni bir hiyerarşi yaratırken normali idealize eder. Yani ideal bir insan yaratarak, diğer herkesin bu standarda uygun hale gelmesi sağlanmaya çalışılır. Cinselliğin Tarihi' nde araştırmasının temelini oluşturan öncü konum şüphesiz cinselliktir. Onun için cinsellik, 
normatif beklenti yaratan ve disipline son derece açık olan bedensel bir davranış biçimidir. Bundan da önemlisi yeniden üretimin sağlanması ve böylece nüfusu oluşturacak biyolojik süreç de yine bu işlevin yaratacağı bir etkidir.

Biyo-iktidarın odağında yer alan sağlı̆̆ın nasıl tanımlandığı konusuna bakıldığında, Dünya Sağlık Örgütü’ nün sağlı̆̆ı, "sadece hastalık ve sakatlık halinin olmayışı değil, bedensel, ruhsal ve sosyal yönden tam iyilik hali”, olarak tanımlamasının yanı sıra, genellikle ölüm ve hastalık gibi olumsuz olguların hesaba katılmadan ele alındığı görülür (Aslantürk, 2016, s.578). Sağlığın sosyal boyutunun ele alınması, biyo-iktidar açısından yorumlamayı kolaylaştırmıştır. Temel tıp bilimlerinde ve klinik bilimlerde bilimsel yöntemin gittikçe artan bir ölçüde ve kullanılışı, teknolojik gelişmelerle birlikte tıp özellikle son yüzyılda önemli bir ivme kazanmıştır (Fişek, 1983, s.24). Japonya, Amerika, Almanya gibi gelişmiş teknolojilere sahip ülkelerde, yaygın hastalıklara yönelik yeni tedavi yöntemleri deney yoluyla sınanmaktadır. Hatta, insan anatomisinin sınırları zorlanmaktadır, örneğin, erkeğe ihtiyaç duyulmadan kadının doğum ilerleyen yıllarda doğum yapabileceğinin mümkün olabileceği açıklanmıştır.

\section{Foucault ve Biyo-Politika}

Foucault'ya göre biyo-politika, biyolojik belirleyenlere geri dönen politik süreçlerin ve kurumların izini sürmekten kopuştur. Bunun yerine politikanın merkezine hayatı koyarak tarihsel süreçleri irdeler. Ona göre, politika tarih dışı değildir, aksine politikadaki tarihsel kopuş teşhis edilmesi gereken önemli bir ayrıntıdır. Biyo-tarih olarak adlandırdığı bu alan tarihsel sürecin biyolojik yaşam süreçleriyle nasıl çakıştığını anlamamıza yönelik bir çabayı ifade etmektedir (Arpacı,2016, s.95). Başka bir ifade ile Foucault, biyo-politikayı tanımlarken yeni sorunları geleneksel politika kurumlarına eklemlememektedir.

Biyo-politikayı üç farklı şekilde tanımlamaktadır: Birinci tanıma göre biyo-politika egemen gücün (yani nitelenen politikanın) pratikte yaşadığı tarihsel kopuştur. İkinci olarak biyo-politika, modern ırkçılığın yükselişinde katalizör etkiye sahip mekanizmadır. Üçüncü tanıma göre ise biyo-politika, bireyin kendini yönetmesinin ve toplumsal düzenlemenin dengesini kuracak olan -liberalizmle ortaya çıkan- yönetim sanatıdır. Burada sözü gelmişken Foucault'nun zaman zaman biyo-politika yerine biyo-iktidar kavramını kullandığını da hatırlatmamız gerekir. Çünkü onun için iktidar, güç ilişkileri tarafından şekillendirilerek, teknolojik gelişmelerle birlikte bireylerin hayatını ortadan kaldırma/kaldırmama kararını verebilecek mekanizmaları elinde bulundurmaktadır:

İktidar her yerde hazır ve nazırdır: Ama bu her şeyi yenilmez birliğinin çatısı altında kümeleştirme ayrıcalığına sahip olmasından değil, her an her noktada daha doğrusu bir nokta ile bir başka nokta arasındaki her bağlantıda ürüyor olmasından kaynaklanır. İktidar her 
yerdedir; her şeyi kapsadığından değil, her yerden geldiğinden dolayı her yerdedir. Ve iktidar sürekli, tekrara dayalı, cansız kendi kendini yeniden üreten her şeyiyle, tüm bu hareketliliklerden yola çıkarak beliren, bunların her birini destek alan ve geri dönerek onları sabitlemeye çalışan genel bir sonuçtur. Şüphesiz adcı (genel kavramların nesnel gerçekliği olmadığını savunan görüş) olmak gerekir: İktidar bir kurum bir yapı değildir; bazılarının baştan sahip olduğu belirli bir güç değil, belli bir toplumda karmaşık bir stratejik duruma verilen addır (Foucault, 2012, s.72).

Hayat ile ölüm üzerinde hakka ilkel biçimde sahip olan bu görünmez el, on yedinci yüzyıldan beri çeşitli dönüşümler geçirmiş, yeni biçimler alarak bütün hayatı yönetme mertebesine erişmiştir (Foucault,2012, s.136). Burada on yedinci yüzyılı anmamızın bir nedeni var: İnsan bedeni üzerinde tahakküm kuracak biyo-teknolojik gelişmeler, tarım ve sanayide çı̆̆ır açılması bu dönemde ortaya çıkan olgulardır. Böylece tarihin bu döneminde biyolojik olan tarihsel olan üzerinde baskı kurmuş; salgın hastalıklar ve kıtlık bahane edilerek hayat üzerinde küçümsenemeyecek bir denetim kurulmuştur. Yani, alanını genişleten iktidar, yaşam süreçlerine karşı sorumluluk alarak geliştirmek yerine, onları denetlemeye girişmiştir (Foucault, 2012, s.142). Açıkcası, Foucault'ya göre 'iktidar, her yerde hazır ve nazırdır' (Iş1k, 2012, s.106).

Biyo-iktidar öldürmekte, ya da en iyi ihtimalle yaşamamıza izin vermektedir. Hayat üzerinde kurulan bu iktidarın iki temel biçimi vardır. İlki bireyin kendi bedenini disipline etme, ikincisi ise hükümetler tarafından düzenlenen nüfus politikalarıdır. İnsan bedeninin üzerindeki hükmetme iradesini de şöyle açıklamaktadır:

Disiplinin tarihsel uğrăğ, bedenin yalnızca yeteneklerine ya da tabiiyatının yoğunlaştırılmasına değil, aynı zamanda itaatkar olduğu kadar yararlı da olmasını sağlayan mekanizmadaki ilişkinin şekillenmesine de yönelen insan bedenine ilişkin bir sanatın doğduğu and1 (Foucault, 1992, s.138).

Foucault' ya göre modernizm ideolojisinin ürünü olan devletlerin sürdürdüğü politikalar gittikçe biyo-politikleşmiştir ve ulusların egemenliği ölüm üzerinde kurulan iktidara dayandırılmıştır. Hayatı sürdürmek yalnızca devletin inisiyatifine kalmıştır. Burada bahsettiğimiz ölüm ve yaşam ise bireyin yaşam hakkı değil, bütün bir nüfusun yaşam hakkıdır.

Covid-19 gibi salgın hastalık vakalarında hastaları tecrit etmek ve salgının yayılmasını mutlak anlamda önlemeye çalışmak yerine aşı tekniğinin geliştirilmesi Foucault'ya göre gücü, güce karşı kullanma yöntemidir. Bilindiği üzere salgına yol açan virüs sağlıklı bedene enjekte edilince, hastalık kontrol edilebilir bir düzeye indirgenir. Böylece de vücudun geliştireceği antikorlar, virüsün bedeni tamamen hasta etmesine izin vermez. Bu olguya nüfusun tümü açısından bakacak olursak, benzeri bir müdahalenin söz konusu olduğunu görürüz. Örneğin belirlenmiş bir nüfus artış oranının nüfusun tamamı için faydalı olacağını düşünelim. $O$ halde 
bu artış eğrisini fiiliyatta bozan -çocuk ölümleri gibi- ögeler bir takım metotlarla azaltılmaya ya da diğer bir yaş grubundaki ölüm oranlarının düşürülmesiyle dengelenmeye çalışılır. Burada amaçlanan şey, çocuk ölümlerini sonlandırmak değil, nüfus artış eğrisini değiştirmeyecek seviyeye ulaştırmaktır (Gambetti, 2012, s.29).

Geleneksel toplumlarda ekonominin odağında bulunan aile kurumunu da derinden sarsan salgın hastalıklarda doğum ve ölüm oranları gibi olguların öneminin ortaya çıkışıyla, hastaneler ve hapishaneler vb. değersizleştirilerek ayrı bir yana konmaktadır. $\mathrm{Bu}$ noktada artık aile nüfusu tabakalara ayrılmış, parçalara bölünmüş en küçük ögesi olmanın ötesine geçemez. Artık önemli olan şey: yönetim zihniyetinde ailenin değerinin ve yerinin büyük oranda kaybedip yerini nüfusun almasıdır. Fakat, işin özünde aile kurumuna duyulan bağlılı̆̆ın devam etmesi özneyi tamamen önemsiz bir konuma geriletmez. Öznenin biyopolitika açısından önemi hala devam etmektedir (Özmakas, 2012, s.65).

Foucault'nun (2000,s.143), bahsettiği bu yeni yönetim zihniyetine göre, hayatlarımızın siyasi, iktisadi, toplumsal ve bireysel bağlamlarının birbirileri ile eklemlenerek ilişki kurduğu bölgelerden oluşan bu yönetim zihniyeti yeni bir tür düzen anlayışı üretilmesine neden olmuştur. Toplumsal tıbbın birbiriyle iç içe geçen ögelerden oluşan dağınık ama anlamlı bir beraberlik içerdiğini söyleyen Foucault, bu toplumsal olana dair kavrayış ve planlamada harekete geçirilecek yeni bir işlevsel zihniyeti de ortaya çıkartır: toplumsal tıp, yaşam ile ilgilenmeyi bir sorumluluk addeden ve bununla beraber yaşama ilişkin olay ve sürelerin toplumsal bedene olan etkisini bulmaya çalışan bir teknolojiyi içerip, kapsar. Her şeyden önce, şehirleşmenin getirdiği karmaşıklık ve düzensizlik fenomenleri içerisinde toplumsal tıbbın çalışma şeklinin "karantina" olduğunu söyleyen Foucault (2013, ss.51-57), karantinanın da aslında bir metafor olduğunu vurgular. Ortaçağda cüzzam salgını ile mücadelede kullanılan yöntemden farklı olarak karantina, hastalığı mekana kapatarak tedavi etmenin adıdır. Salgınla mücadele, hastalığı verili mekanın dışına atma zorunluluğu taşır: şehirleri, hastalıktan ve hastalardan ayrı tutmak için mücadele dışarıda sürdürülür (Baştürk, 2017,s.6).

\subsection{Foucault’nun Biyo-politika Kavramının İzdüşümünde Covid-19 Çıkarımları}

Öznenin, iktidara oynayabilmesi için kitleyi ayartması ve ikna etmesi ayrıca ona meydan okuması gerektiğini savunan Baudrillard'a göre, Foucault bu ayartma ve meydan okuma düzenini reddettiğinden dolayı, iktidarı biyo-politika kavramından faydalanarak, bireyselleştirip maddileştirmeye, somutlaştırmaya çalışmaktadır. Baudrillard'ın savunusuna göre, Foucault iktidara odaklanarak bazı şeyleri gözden kaçırmaktadır. Baudrillard, politikanın sonu olmadığını yalnızca yapısal dönüşümlerin mümkün olduğunu düşünmesine benzer biçimde, ister despotluk düzeninde yaşıyor olalım, isterse disiplin toplumunda, mikro- 
hücre aşamasına kadar biyo-politik müdahalelerde bulunan bir egemenin boyundurluğu altında olduğumuzu iddia etmektedir. Fizikteki simülasyon teorisinin, felsefedeki temsilcisi olan Baudrillard, Nietzsche'nin “en güzel hayal ürünü olan gizli dünya” dediği psikanalizin de bir simülasyon modeli olduğunu iddia ederek, bu durumu biyo-politik referanslarla irdelemektedir. Baudrillard'a göre zihinsel süreçlerimiz de yine egemenler tarafindan kurgulanmış, bireyin eline bir senaryo tutuşturularak bunu oynaması istenmiştir (Baudrillard, 2013, ss.20-40).

Judith Butler, küresel salgının uzamı boyunca yeni bağımlılıklar oluşturduğuna dikkat çekerek, sosyal ilişkilerden yoksun bırakılmamızı tecrit olarak değerlendirmektedir. Ulusal sınırları tanımaksızın evlerimize kadar sızan virüs karşısında yetkililer "ev"e kapanmamızı ifade ederken, Butler önemli bir soru soruyor: "Hangi ev?” Bugün ABD başta olmak üzere dünyanın her yerinde milyonlarca evsiz var. Ayrıca birçok kadın için ev yeterince güvenli değilken, birçok insanın da "aile" diyebileceği yakınları yoktur. İktidar tarafından bir tür korunma alanı olarak yaratılan "aile” formu salgın koşullarında işlevini yitirmiştir. Butler'ın bir sorusu daha vardır: Kimin yaşayacağı ve kimin öleceği sorusu. Düşünürün Kırılgan Hayat (2018) ve Savaş Tertipleri (2015) isimli kitaplarında odaklandığı bu sorunun detaylarını irdelediğimizde, "Hangi hayatlar hayattan sayılır ve hangi hayatların kaybedilmesi halinde yas tutulabilir?" soruları da gündeme gelir. Hayatlarımızın hiç tanımadığımız ve hiçbir zaman da tanıyamayacağımız ismini dahi bilmediğimiz ötekilere doğrudan bağımlı olduğunu savunan Butler başta ABD lideri Trump olmak üzere tüm dünya liderlerinin kimin yaşayacağı ve kimin öleceği sorusunu bir fayda-maliyet problemi olarak çözmeye çalıştı̆ğnı ifade ederken, salgının gündeme getirdiği eşitlik, karşılıklı bağımlılık ve sorumluluk gibi mefhumlarda biyopolitika referansları kullanmaktadır. Virüsün bireyi hasta etme ve öldürme konusunda görece eşitlikçi olduğunu, ama küresel çerçevede yoksul insan topluluklarının aynı biçimde güvencesiz olduğunu ifade eder. Devletlerin ulusal politikalarındaki tedbirsizlikleri nedeniyle, salgına hazırlıksız yakalanılması ve buna rağmen eşitsizliğin, milliyetçiliğin ve kapitalizmin radikal biçimde halklara saldırdığının tanıklığını eden düşünür bu koşulları şaşırtıcı bulmadığını belirtir (Butler, 2020).

Agamben, Türkçeye de kazandırılmış en önemli eseri olan Kutsal İnsan'da bedenin biyo-politika aracılığı ile siyasallaşmasını odağına alırken, egemen iktidarın faaliyete geçtiği anda yaptığ 1 ilk hamlenin biyo-siyasal bir beden yaratmak olduğunu ifade etmiştir. En az egemen iktidar kavramı kadar eski olan bu biyo-siyaset kavramı, modern devletlerin oluşumu ile beraber insanlığın bedensel bütünlüğü ve biyolojik hayatını ekonomik parametreleri hesapladıkları terazilere koymuş ve ne şekilde kendi çıkarlarına hizmet edebileceklerinin 
derdine düşmüştür. İktidar ile en çıplak haliyle bedenlerimizi bağlayan bu gizli bağı temsil eden biyo-siyasal kavramı, Agamben'in ortaya çıkarmak içim mücadele ettiği totaliter rejimlerin çözümlenmesini sağlayacak şeydir (Agamben, 2001, ss.15-16). Düşünürün iddialarına göre, modern devletlerin yönetim biçimi olan demokrasi, kutsal addedilen hayatı ortadan kaldırmasa bile bölüp parçalayarak insan denen varlığı bedene indirgemekte ve böylelikle de onu siyasal çatışmanın nesnesi haline dönüştürmektedir. Siyasetin bu yeni öznesi, tırnak içinde özgür dahi olsa aslında hiçbir statüye ve ayrıcalığa sahip değildir. O artık homo değildir, corpus (gövde)dir. İnsanın insan olmaktan çıkıp bir beden haline gelerek egemenlere tebaa etmesi, onun çıplak hayatının tecrit edilmesi ile tesis edilebilir. Bugünün karantina koşullarına baktığımızda da yine bunu görürüz. Agamben günümüz modern toplumlarının biyo-siyasal mekanizmalarında eskiden en yüksek mertebede hükümdarlar yer alırken, salgın koşulları ile birlikte doktorlar ve bilim insanlarının yeni bir üst mertebeye taşındığını ifade eder. Bunda en büyük etken, ölüm ve hayatın bilimsel bir kavram olmaktan çıkıp, siyasal iktidarın dudağının ucundaki bir karar haline gelmesidir. İkinci Dünya Savaşı sırasında toplama kampında esirlere uygulanan bu yöntem, el değiştirmiş ve kamplar ise şehrin göbeğine, kendi evlerimize taşınmıştır. Agamben'in, Covid-19 üzerine söyledikleri de yine bu yöndedir:

Korku kötü bir rehber fakat [birinin] görmüyormuş gibi yaptığı birçok şeyin ortaya çıkmasına neden oluyor. Sorun, hastalığın ciddiyeti hakkında fikir vermek değil, bu salgının etik ve politik sonuçlarını sorgulamaktır. Ülkeyi felç eden panik dalgasının gösterdiği ilk şey toplumumuzun artık çıplak hayattan başka bir şeye inanmadığıdır. İtalyanların pratikte her şeyi, normal yaşam koşulları, sosyal ilişkiler, iş, hatta arkadaşlıklar, duygusal yakınlıklar ve dini \& politik kanaatler, hastalanma tehlikesine feda etmeye hazır oldukları açıktır. Bu çıplak hayat ve onu kaybetme tehlikesi insanları birleştiren bir şey değil, onları kör eden ve ayıran bir şeydir. Diğer insanlar, Alessandro Manzoni’nin romanında anlatılan vebada olduğu gibi artık yalnızca ne pahasına olursa olsun kaçınması gereken ve kendini en az bir metre uzakta tutması gereken yayıcılar olarak görülüyor. Ölülerin -bizim ölülerimizincenaze hakkı yok ve sevdiklerimizin bedenlerine ne olacağı belli değil. Komşuluklarımız ortadan kaldırıldı ve kilisenin bu konuda sessiz kalması merak uyandırıcı. Bu şekilde yaşamayı alışkanlık haline getiren bir ülkede insan ilişkilerinin ne kadar süreceğini kim bilir? Ve hayatta kalmaktan başka ahlaki değeri olmayan bir toplum nedir? Salgının net bir şekilde ortaya çıkmasına neden olan ve ilkinden daha az rahatsız edici olan diğer şey, hükümetlerin bizi bir süredir alıştırdığı "istisna durumların" normal koşullar haline gelmesidir. Geçmişte daha ciddi salgınlar oldu ama hiç kimse bu nedenle şimdiki gibi acil bir durum ilan etmeyi düşünmedi. Bu durum hareket etmemizi bile engelliyor. İnsanlar uzun yıllar süren kriz ve aciliyet durumlarında yaşamayı o kadar alışkanlık haline getirdiler ki hayatlarının tamamen biyolojik bir duruma indirgendiğini ve durumun sadece sosyal ve politik değil aynı zamanda insan insani ve duygusal boyutu olduğunu fark etmediler. Uzun yıllar olağanüstü durumda yaşayan bir toplum özgür bir toplum olamaz. Aslında "güvenlik nedenleri” denilerek özgürlüğü feda edilen ve bu nedenle kendisini yıllarca süren korku ve güvensizlik durumunda yaşamaya mahkûm eden bir toplumda yaşıyoruz. Virüs için savaştan söz edilmesi şaşırtıcı değil. Acil durum önlemleri bizi sokağa çıkma yasağı koşullarında yaşamaya zorunlu kılıyor. Fakat görünmez bir düşmana sahip olan ve her insanda gizlenebilen bir savaş, en saçma savaştır. Gerçekte ise bu bir iç savaştır. Düşman dışarıda değil, içimizdedir. Endişe verici olan sadece şimdi fazla olan şeyler değil, bundan sonra gelecek olan şeylerdi. Savaşlar, dikenli tellerden nükleer enerji santrallerine kadar bir dizi meymenetsiz teknolojiyi barışa miras bıraktığından, acil sağlık durumundan sonra bile hükümetlerin daha önce gerçekleştiremediği deneylerin devam etmesi için girişimlerde bulunulması muhtemeldir: Üniversite ve okulların kapatılıp çevrimiçi dersler verilmesi, bir araya gelmenin ve politik-kültürel nedenlerle konuşmaların durdurulup 
yerine dijital mesajlaşmanın getirilmesi ve mümkün olan her yerde insanlar arasındaki temas için makinalar temin etmek gibi uygulamalar bu girişimlerdir.

Salgına karşı biyo-politik okumalarla felsefi bir bakış açısı getiren Habermas, tıpkı Sokrates'in dediği gibi, hiçbir şey bilmediğimize dair bir bilgi ile hareket etmek zorunda olduğumuzu ifade eder. Günümüz koşullarında, halk kitle iletişim araçlarından herhangi birini açtığında, devlete tavsiye veren bilim insanların dahi çok az şey bildiğini hayretle takip etmekteyiz. Bu olağan dışı siyasi belirsizliğin, kolektif bilinçte mutlaka iz bırakacağını söyleyen Habermas, neredeyse tüm anayasalarda yer alan "Herkes, yaşama hakkına sahiptir!" maddesini hatırlatarak, hastaların sınıflandırılmasına ve karantina için biçilen zamana karşı çıkmaktadır. İflas eden sağlık sistemleri nedeniyle, hastanelerde yoğun bakım ünitesi bulunamamasını, kendisinin de acı bir şekilde deneyimlediği savaşta yaşanan tıbbi afet senaryolarına benzeten Habermas, kaldırabileceklerinden fazla bir sorumlulukla karşılaşan doktorların hastaları statülerine, kökenlerine ve yaşlarına göre tercih etme noktasına geldiğini ve hiçbir doktorun ölüm ve yaşam üzerine karar verme yetkisi olmadığından, bu durumun anayasada bahsi geçen eşitlik ilkesine son derece ters olduğunu hatırlatmaktadır. Bu durum deontolojinin de en temel ve en sert yasalarından birdir: asla bir insanın hayatı için bir diğerinin hayatından vazgeçilemez. Bu temel etik yasa, doktorları tıbbı kanıtların izinden gitmesi halinde tedavide başarı şansının yüksek olduğu yönünde motive etmektedir. Bir diğer biyo-politik mevzu olan, karantinanın süresi konusunda Habermas, faydacılığın hesap mantığı ile çatışma içerisine girer. Bir tarafta ekonominin canlı tutulması ile diğer tarafta yüksek ölümler yaşanmasını önleme terazisini elinde tutan siyasi liderlerin, tercihlerini ekonomiden yana değil, bireylerin hayatlarından yana kullanması gerekmektedir. Bu nedenle karantina sürecinin, bireylerin özgürlüklerini kısıtlamayacak ölçüde düzenlenmesi gerekir. Habermas, bu pandemi ile yaşananları şöyle özetlemektedir:

Kırılgan alt kültürlerde, birçok harekete geçirici ve dolayısıyla endişe verici faktörler yaşanan dünyadaki deneyimleri etkilemekte: Teknolojik değişim, iş dünyasının devam eden dijitalleşmesi, göç fenomeni, giderek artan çoğulculuk formları vb. Bu endişeler, bir yandan, toplumsal statüyü kaybetmeye yönelik yeterince gerçekçi bir korkuyla ve diğer yandan, politik güçsüzlük deneyimiyle ilişkili. Ancak, Avrupa Birliği'nin her yerinde, milliyetçi barikatların arkasına sığınmak isteyen sağcı popülizmin etkileri, her şeyden önce şu iki şeyden oluşuyor: Ulusal devletin kendi politik aksiyon kapasitesini kaybetmesiyle ortaya çıkan öfke ve gerçek bir siyasi meydan okuma karşısında bir çeşit sezgisel savunma reaksiyonu.

\section{Sağlık Hizmetlerinin Piyasalaştırılması}

Sağlık hizmetlerinin dönüşümü, sanayileşme, kapitalistleşme, ulus-devlet anlayışı, sosyal refah sistemleri bağlamında gerçekleşmiştir. Sağlığın kamusal bir nitelik olarak her bireye bir vatandaşlık hakkı olarak sunulması, kamu otoritesinin güçlü ve sağlı hizmetlerinin kamu tekelinde olduğunu göstermektedir. 
Ulus-devletlerin toplum sağlığı ile ilgilenmesi on altıncı yüzyıla kadar dayandırılmaktadır. On yedinci yüzyılda hızlı sanayileşme, kentleşme vb. salgın hastalıklar gibi sorunlar karşısında devletleri harekete geçirmiştir. On sekizinci yüzyılda sağlık kurumlarının sayıları gönüllüler ve vakıflar tarafından artıılmıştır. Kamusal sağlık örgütlenmelerinin görece erken oluşturulduğu Avrupa'da, devletin doktorları tam zamanlı ve maaşlı olarak istihdam etmesi ancak on dokuzuncu yüzyılda yaygınlaşmaya başlamıştır (Ulutaş, 2011, s.25). Böylece, sağlık hizmetleri kurumsallaşmaya başlamıştır. Yirminci yüzyılda, sağlık evrensellik anlamında sosyal hak olarak kabul görülmüştür.

İkinci Dünya Savaşı sonrası birikim rejimindeki değişimle, dünyanın pek çok yerinde farklı tiplerde Keynesyen refah politikalarının uygulamaya konması, kamusal sağlık hizmetlerini hemen her ülkede sosyal hak statüsüne taşımış ve pek çok ülkede evrensel sağlık hizmeti modeli oluşturulmuştur (Ulutaş, 2011, ss.25-26). 1970'lerin ortalarından itibaren küresel siyasi ve ekonomik krizler Keynesyen politikaları etkisiz bırakmıştır. Yeni dönem, Post-Fordist refah devleti ya da İşletmeci devlet gibi isimlerle anılmaktadır.

Keynesyen modelde meta-dışı bırakılan birçok unsur metalaştırılmaya başlamıştır. Özellikle sağlık gibi kamusal nitelik taşıyan hizmetlerde, örgütlenme ve idare biçimleri değiştirilmiştir. Yeni Kamu İşletmeciliği yaklaşımının hakim olduğu dönemde, kamunun hantallaştığı, kamu harcamalarının arttığ öne sürülerek kamu reformu amaçlanmıştır.

Yeni Kamu İşletmeciliği yaklaşımında üç özellik öne çıkmaktadır: Performansı arttırmak için güçlü bir işletme işlevi, örgütlenmelerde çok sayıda özerk kuruluşların oluşturulması ve piyasalaşma. Özelleştirmeler, taşeronlaşma başlıca dönüştürücü araçlardır. $\mathrm{Bu}$ yaklaşımın öngördüğü yapıda, piyasa koşullarının gerekleri yerine getirilmelidir. Performans standartları ve ölçütleri, birimlerin parçalanması, emek maliyetlerini azaltma, rekabeti artırma çabaları ve sendika gibi örgütlenmelerin işlevini azaltma Yeni Kamu İşletmeciliği yaklaşımının başlıca uygulamalarıdır.

Yeni Kamu İşletmeciliği, görüldüğü gibi sağlık hizmetlerinde piyasalaştırma ve özelleştirmeyi savunmaktadır. Özelleştirme ile, verimliliğin ve etkinliğin artacağı iddiası, bürokratik işleri kolaylaştırmak, yenilenmeyi hızlandırmak ve sağlık hizmetlerine erişimi yaygınlaştırmak adına olumlu görülebilir. Ancak, sağlık kuruluşlarının özelleştirilmesi, yatırımların ve istihdam koşullarının değişmesi anlamına gelmektedir. Kamudan özele kaynak aktarılarak destek ve teşvik sağlanacağı için aslında kamu otoritesi kaybolmayacaktır. Örneğin, kamu hastanelerindeki özel yataklar devlet desteği almakta, özel sağlık sigortaları ve vergi teşvikleriyle desteklenmektedir (Ulutaş, 2011, s.39). 
Sağlık hizmetlerinin piyasalaştırılması ile ilgili olarak başka bir konu da, kamu hizmetlerinde mesleki dönüşümdür. Kamu çalışanları açısından, kamu hizmetlerinin piyasalaştırılması vasıfsızlaşmaya ve yönetsel, örgütsel değişimlere, iş güvencesizliğine yol açmıştır.

Pandemi ile gördüğümüz şey de bunlarla oldukça paraleldir. Hiçbir ülke fark etmeksizin, dünyadaki bütün sağlık sistemleri her yerde salgına hazırlıksız yakalanmış ve sınıfta kalmıştır. Oysaki Sars vb. birçok öncül salgından dersler çıkarılmış olmalı iken neoliberalizm, dünya halklarını krizin ortasına korunmasız biçimde bırakmıştır. Daha da kötüsü, bütün devlet kurumları ve onlar tarafından yönetilen kaynaklar, halk yerine şirketlere ve zengin azınlığa vergi indirimleri ve daha birçok önemli firsatla beraber gümüş tepside sunmuştur. Bugüne kadar bulaşıcı hastalıkları kar getirisi bulmadığı için önemsemeyen ilaç şirketleri, önleyici tedbirlere yatırım yapmadığı için halk sağlığı krizine hazırlanmayı çıkarlarına uygun bulmamışlardır. Ne kadar çok kişi hasta olursa, o kadar çok kazanç elde edileceği böyle bir sistemde, önleyici tedaviler hisse senetlerinin değeri yükseltmeyeceği için, kamu ortaklığında gerçekleştirilebilecek projelere sıcak bakılmamıştır. Tam da bu nedenle, bulaşıcı hastalıkların bile oldukça sınıfsal olduğu ortadadır. Hastalık arttıkça, onlara hizmet etmesi gereken işgücünün cinsiyetlerine ve etni-sitelerine baktığımızda, virüsle teması oldukça yüksek olan bu yeni işçi sınıfının ağırlıklı olarak azınlıklardan ve kadınlardan oluştuğu ortaya çıkmıştır. İşini kaybetme korkusu ile ölüm korkusu arasında seçim yapmak zorunda kalan bu kitle, beraberinde "kimin evden çalışacak kadar şanslı olduğu" sorusunu da akıllara getirmektedir. Toplumsal ayrımı şiddetlendiren bu sorun, cinsiyetçiliğin ve irkçılığın tüm kötü özelliklerini bünyesinde barındırmaktadır (Harvey, 2020).

\subsection{Sağlık Hizmetlerinin Standardizasyonu}

Sağlık çalışanları tarafından benimsenen "Hastalık yoktur, hasta vardır" ilkesi, koruma, teşhis, tedavi ve rehabilitasyon sürecinde her hastanın özgün psiko-sosyal, ekonomik, biyolojik vb. koşullarının göz önünde bulundurulması gereğini ifade etmektedir (Ulutaş, 2011, s.102). Ancak, sağlık hizmetlerindeki dönüşüm, bu ilkenin geçerliliğini sorgulatmaktadır. Piyasalaşma sonucunda ortaya çıkan standardizasyon, rasyonellik ve denetim öğelerini içermektedir.

Günümüzde sağlık kurumları artık ulusal ve uluslararası akreditasyon kuruluşları tarafindan belirlenen teknik standartlara göre değerlendirilmekte ve denetlenmektedir (Ulutaş, 2011, s.103). Çoğu Amerikan kökenli olan akreditasyon kuruluşları, yönetim ve bilgi sistemleri, hijyen konusu, laboratuar hizmetleri, tedavi ve ambulans hizmetleri gibi geniş bir 
çerçevede standardizasyon içermektedir. $\mathrm{Bu}$ standartlara erişim, "kalite" olarak algilanmaktadir.

Diğer taraftan, sağlık hizmetlerinin standardizasyonun kalite olarak algılanması, tıbbın öznelliğinin kaybolmasına neden olmaktadır. Muayeneden tedaviye kadar olan süreçte sağlık personeli, kendileri dışında belirlenmiş yönergelerin uygulayıcıları haline gelmektedir. $\mathrm{Bu}$ durum, sağlık hizmetlerini tek tipleştirmektedir. Tüm tıbbi bakım görevlerinin en küçük parçalarına kadar, her bir işlem için standartların belirlenmesi, farklı bir fiyatlandırmaya ve işbölümüne tabii tutulması, sağlık çalışanlarını insandan uzaklaştırmakta ve insana yabancılaştırmaktadır (Ulutaş, 2011, s.107). Böylece, herhangi bir sağlık eylemi, metalaşma sürecinde kendine kolayca yer bulabilmektedir. Söz konusu süreçte ise, vasıfsızlaşma, işin değersizleşmesi, sağlık çalışanlarının proleterleşmesi ve profesyonelliğin kaybedilmesi gibi sorunlar ortaya çıkmaktadır.

Vasıf ve vasıfsızlaşma kavramları, genellikle uzmanlaşma kavramı ile beraber kullanılmaktadır. Bir iş parçalara ayrılmışsa ve tekrarlanıyorsa "vasıfsız" olarak kabul edilmektedir. Vasıfsızlaşma, artizanal özelliklerin kaybedilmesi, kol ve kafa emeğinin ayrılması, gerekli eğitim düzeyinin azalması, işgücünün artan oranda ikame edilebilir olması ve emek süreci üzerindeki denetimin azalması gibi göstergelerle tanımlanabilmektedir (Schaffer ve Schaffer, 2006 aktaran Ulutaş, 2011, ss.109-110). Doktorların vasıfsızlaşması ise, artizanal vasıfların kaybı ile açıklanmaktadır. Artizanal vasıfların kaybı söz konusu iken buna ek olarak verimliliğe odaklı yeni sağlık yönetim sistemi tüm sağlık çalışanlarından daha fazla vasfa sahip olmalarını, birden fazla birimde çalışmalarını beklemektedir. $\mathrm{Bu}$ durum, çalışanların iş tanımlarının belirsizleşmesine, görevleri ya da uzmanlık alanları dışında olan birden fazla iş yapmalarına neden olmaktadır.

Sağlık çalışanlarının proleterleşmesi meselesi ise, kamu hizmetlerinin metalaşma sürecinde ortaya çıkmaktadır. Ayrıca, doktorlar proleterleşirken diğer sağlık çalışanları profesyonelleşmektedir. Profesyonelleşme, teknolojik gelişmeler ve siyasi, sosyo-ekonomik değişim içerisinde neo-liberal dünyada farklı anlamlar kazanabilen bir kavramdır. Bütün bu gelişmeler, doktorların profesyonelliklerini yitirmelerine ve vasıfsızlaşan proleter bir kitle haline gelmekte olduklarını göstermektedir. Özerkliklerini kaybetmiş, hesap verme üzerine kurulu bir profesyonellik anlayışı gelişmiştir. Standart prosedürler çerçevesinde işlerini yapmaktadırlar. Larson (1980), profesyonellerin proleterleşmesi tezini, doktorların ekonomik, örgütsel ve teknik yabancılaşmanın her üçüne de maruz kaldıklarını ileri sürerek desteklemektedir (Ulutaş, 2011, s.123). Ayrıca, Türkiye'de 5947 sayılı Üniversite ve Sağlık Personelinin Tam Gün Çalışmasına ve Bazı Yasalarda Değişiklik Yapılmasına Dair Yasa’ nın 
yürürlüğe girmesi de doktorların proleterleşmesi tartışmalarına ivme kazandırmıştır (Ulutaş, 2011, s.126).

\subsection{Sağlık Hizmetlerinde Teknolojik Dönüşüm}

Bütün bu dönüşüm içerisinde, ortaya çıkan neden-sonuç ilişkilerinin temelinde teknoloji bulunmaktadır. Teknoloji, evrensel anlamda siyasi, ekonomi ve sosyal gelişmelerin belirleyicisi olarak karşımıza çıkmaktadır. Tıbbi teknoloji ise, tıbbı bakım için kullanılan ilaç. araç ya da tıbbi veya cerrahi prosedürdür (Cook, Cook-Deegan, 1988 aktaran Ulutaş, 2011, s.133).

Teknolojinin mülkiyeti, bilgisi ve denetimi sermayenin elindedir (Ulutaş, 2011, s.134). Sağlık hizmetleri piyasalaştıkça, sağlık çalışanlarının teknoloji üzerindeki hakimiyeti azalmaktadır. Örneğin, doktorlar bugün hangi testlerin hastane tarafından yapılacağına, hangi ilaçların piyasaya sürüleceğine ve masrafların ne kadarının sigorta kapsamında olacağına karar verememekte ancak hangi testlerin yapılması gerektiğini ve hangi reçetelerin yazılacağını belirleyebilmektedir.

Tıbbi teknolojideki gelişmeler, çok sayıda hastalığın tedavisinde ilerlemeyi getirmiştir (Ulutaş, 2011, s.137). Yeni tetkik cihazlarının geliştirilmesi, ilaç teknolojisinin ilerlemesi teşhis ve tedavi süresini azaltmıştır. Ancak, buradaki sorun teknolojik ilerleme değil, teknolojinin hangi amaçlarla geliştirildiği, kullanıldığı ve mülkiyetinin kime ait olacağıdır.

\section{Sonuç}

Foucault'nun tehlikeler çağı adını verdiği günümüzün liberal toplumlarında, insanlar hayatlarını ve yaşadıkları zamanla birlikte tüm geleceklerini de tehlike olasılığı olarak algılamaya şartlandırılmıştır. Bu durum on dokuzuncu yüzyılda yaşanan gelişmelerle beraber başlamış olsa da, Avrupa'nın en büyük travmalarından birinin yaşandığı, on yedinci yüzyılda da geçerlidir. O dönemin halet-i ruhiyesine şekil veren veba salgını, tüm halkların hayal edebileceği en büyük tehditti. Günümüzde aynı şeyleri yaşadığımızı görme şansı olmayan Foucault, mahşerin dört atlısının on dokuzuncu yüzyıl ile kaybolduğunu, bunun yerini ise gündelik yaşam pratiklerindeki tehditlerin aldığını söylemekteydi. Düşünüre göre, hastalık ve hijyenle ilgili yürütülen devlet kampanyaları yozlaşma korkusu etrafında dönmektedir. “Korku, liberalizmin şartıdır” diyen Foucault, tehlike kültürünün yokluğunda, liberalizmin varlığını sürdüremeyeceğine işaret etme gayretindedir. Bugün de yine kitle iletişim araçlarından herhangi birini açtığımızda maruz kalacağımız haber akışlarında, aynı korku kültlerini görürüz. Toplumu bilinçlendirmek yerine halk üzerinde korku yaratarak, onların iradelerini gasp etme gayesi taşıyan bu tür bir habercilik anlayışı, söz konusu biyo-politik 
saldırıyı gerçekleştiren ellerin ürünüdür elbette. Tam bu noktada, bu salgın ya da saldırı ile mücadele etmeyi lokal ölçekle gerçekleştirilebilmenin formülünü arayacak olduğumuzda Foucault'nun kullandığı temel kavramlardan biri olan "yönetim sanatı" kavramı ile karşılaşırız. Bu kavramı tartıştığı derslerinde düşünür, cüzzam ve veba salgınlarında toplumdan dışlanan hastaların içeride tutulmasını bir başka kavramla ifade edecek olursak “büyük kapatılma” ya maruz kalmalarını, yönetim sanatının tam zıddı olarak gördüğünü ifade eder. Yani burada bir yönetilememe durumu söz konusudur. Klasik çağda icat edildiğini düşündüğü devlet ya da aile gibi iktidar teknolojilerinin, çocukları, delileri, fakirleri, işçileri ve tüm hastaları yönetecek şekilde tasarlandığını ifade etmektedir. Zaten Foucault, yukarıda verdiğimiz haber örneğinde olduğu gibi, yönetim denen şeyin bireylerin iradesinin nakli üzerine kurulu olduğunu savunmaktadır.

Ayrıca, sağlığın metalaşması sonucunda oluşan "sağlık talebi (ya da türetilmiş talep olarak sağlık)" , sermaye birikiminin kar sağlama yolu olarak görülmektedir. Sağlık talebi doğrultusunda tedavi ve ilaç ihtiyacı duymak kaçınılmazdır. Kapitalizmin, biyo-politika aracılığıyla elbette, sağlık talebini kalkınma üzerinden toplumsal refahın yükselmesinin ilk koşulu haline getirmiş olması önemlidir. Ancak, ülkeler arasındaki gelişmişlik düzeyi sağlık alanında da fark etmektedir. Yoksul ülkelerde, sağlık talebi bir "sağlık hakkı"4 olarak görülse bile zengin ülkelerdeki gibi “sektörleşme” den söz etmek pek mümkün değildir. Sağlık sektörleşmesinin ya da sağlık kapitalizminin varlığ 1 hissedilmemesine rağmen, söz konusu ülkelerde gerçek bilimsel ilerlemeler yaşanmaktadır. ABD tıp alanında "dünya lideri” olarak sunulurken, gerçekte sadece sağlıktaki piyasa başarısızlığında liderliği elinde bulunduruyor: Devasa ulusal gelirinin neredeyse beşte birini sağlığa ayırdığı halde, kişi başına gelir rakamlarında kendisinin ancak yirmide birine ulaşabilen komşu ülke Küba'dan bazı bakımlardan biraz daha ileri, bazı bakımlardansa daha geri sonuçlar elde ediyor (Leys, 2009,s.1). Küba'nın sağlık alanındaki gelişmişliği, koruyucu sağlık politikalarının etkinliğine bağlanmaktadır.

Sadece ülkeler arasında değil, bir toplumdaki sınıflar arasındaki sağlık talebi ve sağlık hakkı anlayışı ve bu alanın işleyişi de farklıdır. Kapitalizmin, ve dolayısıyla biyo-politikanın, her zaman başarılı olarak kendini ayakta tutma aracı sınıfsal eşitsizliği yönetmek olmuştur. $\mathrm{Bu}$ yönetim emek piyasasının seyrindeki ücret-kar dengesini bozarak ve sosyal güvenlik, kamu hizmetleri vb üzerinde sermayenin etkisini arttırarak gerçekleşmektedir. Sağlık kapitalizmi de bu yollarla yaygınlaştırılmıştır. Yoksul insanların daha fazla maruz kaldığı,

\footnotetext{
${ }^{4}$ Sağlık hakkı, her şeyden önce insan hakkıdır. İnsan Hakları Evrensel Bildirgesi, Avrupa Sosyal Şartı ve Türkiye'de Anayasa vb. bu hak tanınmıştır.
} 
enfeksiyonlar, beslenme yetersizliği, kronik hastalıklar ve yaralanmalar gibi bedensel riskleri de doğrudan beraberinde getiren olumsuz maddi koşullar; gecikmiş veya bozuk kavramsal ya da sosyal gelişim gibi kişisel gelişim temelli sorunlar; toplumsallaşma, iş yaşamına hazırlanma ve aile yaşamı benzeri toplumsal sorunlar; ayrıca, bir araya gelerek bileşik bir etki yaratan tüm bu etmenler arasındaki etkileşim, farklı yaşlarda çeşitli hastalıkların önünü açmaktadır (Raphael, 2006 aktaran Leys, 2009, s.22).

Bu noktada, COVID-195 pandemisi karşısında sağlık kapitalizminin, ve elbette ki biyo-politikanın, rotası bilinmemektedir. Hastalığa yol açan virüsün çok çabuk yayılması, semptomların değişiklik göstermesi, alınan önlemlerin yetersiz kalması, tedavi için bir ilacın bulunamaması gibi nedenler bu pandeminin küresel sağlık yönetimini de tekelini de sarsmıştır. Daha önce yaşanan küresel (veba, kolera, tifüs gibi) salgınlar, dikkatleri sağlık sektörünün tedavi ve ilaç tarafına çevirmiştir. Hızlı ve etkili tedavi arayışı içinde hastalığa çare bulmak amacı ilaç endüstrisini canlandırmıştır. İlaç endüstrisi, siyasi ve sosyo-ekonomik ilişkileri de barındırmaktadır. Sağlık kapitalizminin bu salgınlardan çıkış yolu olarak ilaç endüstrisini seçmesi, en rasyonel yoldur. İlaç endüstrisi, biyo-teknolojik gelişmelerle daha da genişlemiş; küresel kapitalist ağların kontrolünde yerini almıştır. Örneğin, 2008 yılında dünya genelinde ilaç satış tutarının 600 milyar dolar seviyesine ulaşmıştır. Bu tutarın üçte ikisini, büyük kısmı Amerika veya Batı Avrupa merkezli olan yirmi büyük şirket paylaşmıştır (Leys, 2009,s.28). 2018'de ise, dünya genelinde ilaç sanayine yönelik harcamalar 1 trilyon 200 milyar dolar seviyesinde gerçekleşmiştir. ${ }^{6}$

Bugün, COVID-19 pandemisinden kurtulmak için yine tedavi sürecine odaklanılmış, ilaç endüstrisinde çare aranmaktadır. Şu ana kadar aşı çalışmaları devam etmektedir. Deneysel tedaviler dahilinde anti-viral ilaçlar denenmektedir.

Diğer taraftan, hastalığın tedavisinde kullanılacak olan aşı bulunana kadar izlenen strateji, yayılma hızının yavaşlatılmasına yöneliktir. Yayılma hızının yavaşlatılması; kişisel hijyenin devamlılı̆̆ı, "sosyal mesafe" nin korunması, insanların ortak dış alanlarda bulunmaması, evde karantinaya girmeleri şeklinde, siyasi erk politikası doğrultusunda, sağlanmaya çalışılmaktadır. $\mathrm{Bu}$ önlemlerin sosyolojik, psikolojik ve ekonomik sonuçları oluşacaktır. COVID-19 pandemisi, derin bir küresel iktisadi kriz doğuracaktır. Oluşan iktisadi kriz, yukarıda bahsettiğimiz sağlık talebi ve tedavi, ilaç ihtiyacında sınıfsal tercihlerde tekrar belirleyici olacaktır.

\footnotetext{
${ }^{5}$ Yeni Koronavirüs Hastalığı hakkında ayrıntılı bilgi için ayrıca bkz. https://covid19bilgi.saglik.gov.tr/tr/ (Erişim Tarihi: 12.04.2020).

${ }^{6}$ Ayrıntılı bilgi için bkz. https://home.kpmg/tr/tr/home/gorusler/2019/04/sektorel-bakis-2019-ilac.html (Erişim Tarihi: 12.04.2020).
} 
Türkiye'de biyo-politika, kendisini iç ve dış siyasi, ekonomik ve sosyolojik olaylar üzerinden göstermektedir. Uygulanan sağlık hizmetleri, bireylerin sosyo-ekonomik durumları ve ülkenin kalkınma politikasına bağlı olarak sınıflar bazında eşitsizlik yaratabilmektedir. İktidarların yönetim gücünü ellerinde tutma çabası, bireylerin sağlık, eğitim, haberleşme gibi temel vatandaşlık haklarını sınırlayabilmektedir. Diğer taraftan, toplum içerisinde, nadiren, genel barışı sağlayabildikleri de görülmektedir.

Küresel dünya ile temas bu noktada ayrı önem taşımaktadır. Gelişen teknoloji, hayatın her alanında etkilidir. Sağlık uygulamaları açısından teknoloji ele alındığında, bireylerin hastalıkları, sakatlıkları, hastalığa yakalanma ihtimalleri, muayene ve tedavi süreçleri daha özelleşmiştir. Bireyin sağlı hizmetlerine erişimini kolaylaştırmak amacıyla birey takip altındadır.

\section{Kaynakça}

Abdurrahman, Aydın (2016). Giorgo Agamben: Etten Ibaret Insan ve Biyopolitika Makinesi. Biyopolitika 2. Cilt Foucault'dan Günümüze Biyopolitikanın İzdüşümleri. Ankara: NotaBene Yayınları.

Agamben, Giorgio (2001). Kutsal Hayat: Egemen Iktidar ve Çıplak Hayat. Istanbul: Ayrıntı Yayınları

Agamben, Giorgio (2020). L'invenzione di un'epidemia (Hayatta kalmaktan başka ahlaki değeri olmayan bir toplum nedir?) Uni-Versus Sosyal Araştırmalar Merkezi.

Arpacı, M. (2016). Foucault, biyopolitika ve biyotarih: tarihsel çalışma alanları olarak tıp, beden ve nüfus. ViraVerita E-Dergi, Sayı 3, ss.80-98.

Aslantürk, H. (2016). Türkiye'de biyo-iktidar açısından sağlık hizmetleri ve kadın. Türkiye Sosyal Araştırmalar Dergisi, Sayı: 3, ss.573-595.

Baştürk, Efe (2013). Bir Kavram İki Düşünce: Foucault'dan Agamben'e Biyopolitikanın Dönüşümü. Alternatif Politika Dergisi, Cilt 5, Sayı 3

Baştürk, Efe (2017) Biyopolitika ve Savaşım: Foucault ve Agamben Arasındaki Ayrımın Kavramsal İçeriği. Marmara Üniversitesi Siyasal Bilimler Dergisi, Cilt 5, Sayı 2

Baudrillard, Jean (2013). Foucault'yu Unutmak. Ankara: Doğu Batı Yayınları

Bayar, F. (2008). Küreselleşme kavramı ve küreselleşme sürecinde Türkiye. Uluslararası Ekonomik Sorunlar Dergisi, Sayl: XXXII, 25-34.

Butler, Judith (2015). Savaş Tertipleri: Hangi Hayatların Yası Tutulur? Yapı Kredi Yayınları, Istanbul.

Butler, Judith (2018). Kırılgan Hayat: Yasın ve Şiddetin Gücü, Metis Yayınları, Istanbul.

Butler, Judith (2020). Capitalism Has its Limits: discuss the COVID-19 pandemic, and its escalating political and social effects in America, Verso Books.

Fişek, N. (1983). Halk să̆lı̆̆ına giriş. Ankara: Hacettepe Üniversitesi Dünya Sağlık Örgütü Hizmet Araştırma ve Araştırmacı Yetiştirme Merkezi Yayını. No.2. 
Foucault, M. (1986). Toplumu Savunmak Gerekir. İstanbul: Yap1 Kredi Yayınları.

Foucault, M. (1992). Hapishanenin Doğuşu. Ankara: İmge Kitabevi.

Foucault, M. (2000). Büyük Kapatılma. İstanbul: Ayrıntı Yayınları

Foucault, M. (2011). Özne ve İktidar. İstanbul: Ayrıntı Yayınları

Foucault, M. (2012). Cinselliğin Tarihi. İstanbul: Ayrıntı Yayınları

Foucault, M. (2015). Biyopolitikanın Doğuşu: College De France Dersleri (1978-1979). Istanbul: Bilgi Üniversitesi Yayınları

Gambetti, Zeynep (2012). Foucault'dan Agamben'e Olağanüstü Halin Stradanlı̆̆ına Dair Bir Yanit Denemesi. Cogito Dergisi: Foucault Sayıs1:70-71, Istanbul: Yap1 Kredi Yayınları.

Habermas, Jürgen (2015). Dans cette crise, il nous faut agir dans le savoir explicite de notre non-savoir. Le Monde Gazetesi

Harvey, David (2020). Anti-Capitalist Politics in the Time of Covid-19, Jacobin Magazine

Işık, S. (2012). Foucault'da iktidar, özgürlük ve direniş. Ekev Akademi Dergisi Cilt: 16 Sayl: 51. ss.103-114.

Kay, L. (1993). TheMolecularVision of Life: Caltech, theRockefeller Foundation, andthe Rise of New Biology. New York: Oxford University Press.

Keyder, Ç. (2011). Giriş. Avrupa'da ve Türkiye'de sağlık politikaları. Ç.Keyder, N.Üsündağ, T. Ağartan, Ç Yoltar (Ed.), ss.15-35. İstanbul: İletişim Yayınları.

Kürkçü, D.D. (2013). Küreselleşme kavramı ve küreselleşmeye yönelik yaklaşımlar. The Turkish Online Journal of Design, Art and Communication - TOJDAC. Volume 3 Issue 2.

Lemke, Thomas. (2013). Biyopolitika. İstanbul: İletişim Yayınları

Leys, C. (2009). Sağlık ve Kapitalizm. Kapitalizmde Sağlık: Sağlıksızlık Semptomları. İstanbul: Yordam Kitap

Özmakas, Utku (2012). Foucault: İktidardan Biyoiktidara. Cogito Dergisi: Foucault Sayıs1:70-71, Istanbul: Yap1 Kredi Yayınlar1.

Ünlütürk Ulutaş, Ç. (2011). Proleterleşme ve Profesyonelleşme Tartışmaları Işı̆̆ı̆nda Türkiye'de Sağllk Emek Sürecinin Dönüşümü. İstanbul: Nota Bene Yayınları

Yalçınkaya, T. (2010). Küreselleşme sürecinin ekonomi politikaları üzerine etkilerinin analizi: türkiye örneği. Doktora Tezi. Dokuz Eylül Üniversitesi, Sosyal Bilimler Enstitüsü. İzmir.

www.covid19bilgi.saglik.gov.tr/tr/ (Erişim Tarihi: 12.04.2020).

www.home.kpmg/tr/tr/home/gorusler/2019/04/sektorel-bakis-2019-ilac.html (Erișim Tarihi: 12.04.2020).

www.who.int/medical_devices/assessment/en/ (Erişim Tarihi: 01.11.2018). 